\title{
Effect of UV-A and UV-B on diel patterns of growth and metabolic activity in Nannochloris atomus cultures assessed by flow cytometry
}

\author{
Cristina Sobrino ${ }^{1,2, *}$, Olimpio Montero ${ }^{1}$, Luis M. Lubián ${ }^{1}$ \\ ${ }^{1}$ Instituto de Ciencias Marinas de Andalucía (CSIC), Avenida. República Saharaui 2, Puerto Real, Cádiz 11510, Spain \\ ${ }^{2}$ Present address: Smithsonian Environmental Research Center, PO Box 28, Edgewater, Maryland 21037, USA
}

\begin{abstract}
The aim of this study was to assess the effect of UV-A (320 to $400 \mathrm{~nm}$ ) and UV-B (280 to $320 \mathrm{~nm}$ ) radiation on diel patterns of growth and metabolic activity of the marine picoplankter Nannochloris atomus using flow cytometry. $N$. atomus cells exposed to PAR (400 to $700 \mathrm{~nm}$ ), PAR+UV-A and PAR+UV-A+UV-B showed clear diel patterns in cell size, chlorophyll fluorescence and metabolic activity, the latter being measured by a fluorescein diacetate-based cell esterase activity assay. For all spectral treatments, patterns increased during the day and decreased during the night, with minima near dawn and maxima near dusk. In addition, cell division was tightly phased to the light dark (L:D) cycle, occurring soon after dark. Exposure to UVR did not alter the synchrony of the parameters measured, but the extent of variation between dawn and dusk was dependent on the spectral conditions. Chlorophyll autofluorescence and metabolic activity decreased to a larger extent when cells were exposed to UV-B than in treatments where UV-B was excluded. In contrast, the cell size was larger under the treatment including UV-A+UV-B than under the treatment including only UV-A. These results show that UV-B damage can decrease growth and metabolic activity in $N$. atomus without altering the synchronization of the diel patterns, and contribute to a better understanding of phytoplankton behavior under UVR exposures.
\end{abstract}

KEY WORDS: UV radiation $\cdot$ Diel cycles $\cdot$ Flow cytometry $\cdot$ Nannochloris atomus Resale or republication not permitted without written consent of the publisher

\section{INTRODUCTION}

Within the solar radiation that reaches the Earth's surface, the short wavelengths of UV-B (280 to $320 \mathrm{~nm}$ ) are the most damaging and are also increasing due to stratospheric ozone depletion (Madronich et al. 1998). UV-A radiation (320 to $400 \mathrm{~nm}$ ), with less energy per wavelength, nevertheless occurs at a higher irradiance than UV-B and can be responsible for inhibitory processes as well. However, it also plays an important role in the activation of repair processes that counteract the negative UV-B effects (Quesada et al. 1995).

In some phytoplanktonic species, the continuous periodicity of the light:dark (L:D) cycles gives rise to internal cycles that are displayed as synchronized diel cycles of behavior (Olson \& Chisholm 1986, Jacquet et al. 2001a,b). Pronounced diel patterns of variation with minima near dawn and maxima near dusk have been described for cell size, cell-specific beam attenuation and absorption, chlorophyll fluorescence and carbon content (DuRand \& Olson 1998, Jacquet et al. 2001a,b), which can be properly ascertained by flow cytometry (FC). These diel patterns are linked to photosynthetic metabolism during the day, and to respiratory metabolism during the darkness (DuRand \& Olson 1998). Photosynthesis and respiration, along with many other biological processes in the cell, such as DNA replication or nutrient uptake and fixation, are susceptible to UVR damage (Cullen \& Lesser 1991, Beardall et al. 1997, Buma et al. 2003, review by Vincent \& Neale 2000).

Nannochloris atomus, a marine chlorophyte, is similar in size (ca. $2 \mathrm{~mm}$ diameter) to oceanic picoplankton, which are considered one of the principal contributors to both primary production and biomass in open waters 
(Li 1994). It has been reported that Nannochloris sp. shows pronounced diel cycles of growth and cell division (DuRand \& Olson 1998). Since UVR could damage many processes in the cell, as well as the genes responsible for the synchronization, we hypothesized that UVR damage to the cells might also affect synchronicity in $N$. atomus, showing abnormal or missing patterns of decreased growth and metabolic activity measured by a cell viability assay (Dorsey et al. 1989). The aim of this study was to assess the effect of UV-B and UV-A radiation on the diel patterns of growth and metabolic activity in $N$. atomus using FC along with cell counting and pigment analysis. In addition, the results of this study will be useful for the interpretation of the signals detected by FC in UV-exposed waters.

\section{MATERIALS AND METHODS}

Organisms and culture conditions. Nannochloris atomus Butcher (Chlorophyceae) cultures were provided by the M.M.C.C. of Instituto de Ciencias Marinas de Andalucía (CSIC, Spain). The growth medium was filtered and sterilized seawater enriched with f/2 nutrients. Nutrient-replete cultures were maintained at $20^{\circ} \mathrm{C}$ with continuous aeration to avoid prolonged self-shading between cells and to observe exclusively the effect caused by UVR.

Experimental setup. Cultures $(n=2$, $650 \mathrm{ml}$ ) were grown in UVR transparent Plexiglas cylinders (Plexiglas XT[r] 29080) for $7 \mathrm{~d}$ in a growth chamber (Koxka, Hussman Koxka S.L.) under a 12:12h L:D photoperiod. Cylinders were wrapped with cellulose acetate cut-off filters to generate 3 different spectral treatments: P (mainly PAR >395 nm), Ultraphan 395 (Digefra, Ref. URUV); PA (mainly PAR and UV-A $>320 \mathrm{~nm}$ ), Folex 320 (Folex, Ref. 10155099); PAB (PAR, UV-A and UV-B > $295 \mathrm{~nm}$ ), Ultraphan 295 (Ref. URT 100). Each day, the cylinders were also progressively uncovered, during the first half of the light period, and progressively covered, during the second half of the light period, with 0,1 , 2 or 3 neutral density screens (plastic window screen) to simulate the increase and decrease in irradiance observed under natural solar exposures which promotes cell acclimation (Table 1).

PAR, UV-A and UV-B irradiances were provided by Sylvania Daylight, Q-panel 340 and Philips TL 40 W/12 lamps, respectively. The irradiance for each treatment was measured in situ inside the cylinders with a spherical quantum sensor (Zemoko, P20HM33CM12KG) connected to a LI-1000 data logger (Li-Cor) for PAR, and a Dr. Gröbel RM-11 (UV-Elektronik) broadband radiometer equipped with sensors for UV-A and UV-B. Spectral irradiance from 300 to $800 \mathrm{~nm}$ was also measured with a LI-1800 UW spectroradiometer (Li-Cor) covered with the same filters (Plexiglas, cellulose acetate and neutral screens) as those covering the cylinders for each case. Maximum PAR irradiance used was $193 \mu \mathrm{mol}$ photons $\mathrm{m}^{-2} \mathrm{~s}^{-1}\left(42 \mathrm{~W} \mathrm{~m}^{-2}\right)$, with UV-A and UV-B then being calculated from this PAR value to simulate natural sunlight PAR:UV-A:UV-B ratios. The sunlight values used as reference were calculated from the PAR, UV-A and UV-B irradiances measured at noon during the month of July at Cádiz Bay $\left(36^{\circ} 65^{\prime} \mathrm{N}\right.$, $\left.06^{\circ} 25^{\prime} \mathrm{W}\right)$. Light values were achieved by combining PAR, UV-A and UV-B lamps and modifying the distance to the cylinders. Weighted irradiance values were obtained by applying a biological weighting function for the inhibition of Nannochloris atomus photosynthesis by UVR (Sobrino et al. 2005) and the DNA damage action spectrum (Setlow 1974). Further details on the experimental setup are reported in Sobrino et al. (2004).

Table 1. PAR, UV-A and UV-B intensities utilized for Nannochloris atomus exposures measured with a LI-1800 UW spectroradiometer. Values show unweighted $\left(\mathrm{W} \mathrm{m}^{-2}\right)$ and weighted irradiances for each spectral range with 0,1 , 2 and 3 neutral density screens, depending on the time period. Weighted irradiance values were obtained by applying the biological weighting function for $N$. atomus photoinhibition (Sobrino et al. 2005) and the DNA damage action spectrum (Setlow 1974)

\begin{tabular}{|c|c|c|c|c|}
\hline \multirow{2}{*}{$\begin{array}{l}\text { Neutral screens } \\
\text { Time period }\end{array}$} & \multirow[t]{2}{*}{ Irradiance } & \multicolumn{3}{|c|}{ Spectral range } \\
\hline & & $\begin{array}{c}\text { PAR } \\
(400-700 \\
\mathrm{nm})\end{array}$ & $\begin{array}{c}\text { UVA } \\
(320-400 \\
\mathrm{nm})\end{array}$ & $\begin{array}{c}\text { UVB } \\
(300-320 \\
\mathrm{nm})\end{array}$ \\
\hline 3 neutral screens & Ratio PAR:UVA:UVB & 100 & 10.41 & 1.78 \\
\hline $08: 00-9: 00$ & Unweighted ( $\mathrm{W} \mathrm{m}^{-2}$ ) & 14.03 & 1.46 & 0.25 \\
\hline \multirow[t]{2}{*}{ 19:00-20:00 } & $\begin{array}{l}\text { Photoinhibition } \\
\text { (dimensionless) }\end{array}$ & & 0.08 & 0.13 \\
\hline & DNA damage $\left(\mathrm{mW} \mathrm{m}^{-2}\right)$ & & 0.13 & 28.87 \\
\hline 2 neutral screens & Ratio PAR:UVA:UVB & 100 & 10.94 & 1.72 \\
\hline $09: 00-10: 30$ & Unweighted $\left(\mathrm{W} \mathrm{m}^{-2}\right.$ ) & 20.39 & 2.23 & 0.35 \\
\hline \multirow[t]{2}{*}{$17: 30-19: 00$} & $\begin{array}{l}\text { Photoinhibition } \\
\text { (dimensionless) }\end{array}$ & & 0.13 & 0.18 \\
\hline & DNA damage $\left(\mathrm{mW} \mathrm{m}^{-2}\right)$ & & 0.21 & 40.32 \\
\hline 1 neutral screen & Ratio PAR:UVA:UVB & 100 & 11.35 & 1.95 \\
\hline $10: 30-12: 30$ & Unweighted (W m²) & 28.17 & 3.17 & 0.55 \\
\hline \multirow[t]{2}{*}{$15: 00-17: 30$} & $\begin{array}{l}\text { Photoinhibition } \\
\text { (dimensionless) }\end{array}$ & & 0.18 & 0.29 \\
\hline & DNA damage $\left(\mathrm{mW} \mathrm{m}^{-2}\right)$ & & 0.29 & 63.73 \\
\hline 0 neutral screens & Ratio PAR:UVA:UVB & 100 & 10.54 & 2.00 \\
\hline \multirow{3}{*}{$12: 30-15: 00$} & Unweighted $\left(\mathrm{W} \mathrm{m}^{-2}\right)$ & 42.01 & 4.85 & 0.84 \\
\hline & $\begin{array}{l}\text { Photoinhibition } \\
\text { (dimensionless) }\end{array}$ & & 0.28 & 0.44 \\
\hline & DNA damage $\left(\mathrm{mW} \mathrm{m}^{-2}\right)$ & & 0.46 & 99.23 \\
\hline
\end{tabular}


Cell density and chlorophyll content. Samples for cell density and chlorophyll measurements were collected $2 \mathrm{~h}$ after the light was on. Cells were counted in triplicate aliquots using a Neubauer haemacytometer. Growth rates $\left(\mu, \mathrm{d}^{-1}\right)$ were calculated as the slope of $\ln$ $N(t)$ vs. time, during the exponential growth phase (Days 2 to 6 , inclusive), where $N(t)$ was the averaged cell density on Day $t$. Chlorophyll a concentration was measured in triplicate aliquots for each culture concentrated by centrifugation $\left(1726 \times g, 15 \mathrm{~min}, 4^{\circ} \mathrm{C}\right)$; pigments were extracted from the pelleted cells with $100 \%$ methanol, and quantified using the equations of Porra et al. (1989).

Flow cytometry. Samples for FC were collected every $2 \mathrm{~h}$ from the end of Day 3 to the beginning of Day 5 . They were analyzed using a FACScalibur flow cytometer equipped with a $488 \mathrm{~nm}$ excitation argon laser and the data were computed with CellQuest software (Beckton-Dickinson).

Triplicate subsamples for each culture were analyzed for $30 \mathrm{~s}$ (6000 to 10000 events per measurement) immediately after collection. Signals of forward-angle light scatter (FSC) and side-angle light scatter (SSC), chlorophyll autofluorescence (FL3, >630 nm), and fluorescein fluorescence (FL1, 515 to $545 \mathrm{~nm}$ ) were recorded and used as indicators of the cellular size, chlorophyll fluorescence and metabolic activity, respectively. The relationship between FSC and SSC signals and the cellular size was ascertained by comparison with data from a Coulter Counter (Model ZM, Coulter Electronics). The following correlations were obtained for Nannochloris atomus cells:

$$
\begin{array}{ll}
\text { FSC }=163.66 \log (\text { vol })+6.38 & \mathrm{r}^{2}=0.92, \mathrm{n}=16 \\
\mathrm{SSC}=18.18 \log (\mathrm{vol})-0.06 & \mathrm{r}^{2}=0.72, \mathrm{n}=16
\end{array}
$$

Metabolic activity was assessed using a fluorescein diacetate-based cell esterase activity assay, which has been correlated with cellular metabolic activity (Dorsey et al. 1989) (FDA, Ref. 20164-2, SigmaAldrich). FDA is a hydrophobic and non-fluorescent dye that penetrates the cell plasma membrane due to its small size (mol. wt 416). Once inside the cell, nonspecific esterases break down the molecule resulting in fluorescent fluorescein, which can be quantified by FC. Using a saturating FDA solution, the fluorescein will accumulate only in cells with intact membranes, proportionally to the cell esterase activity. The response from non-stained Nannochloris atomus cells was indicative of non-viable cells, and thus used to determine the lowest fluorescence emission. FDA solution $(10 \mathrm{ml})$ was added to $1 \mathrm{ml}$ aliquots of $N$. atomus cultures exposed to each spectral treatment and vortexed gently (Sobrino et al. 2004). Samples were maintained in the dark for 15 min for stain incorporation until fluorescence emission was registered by the FL1 photomultiplier. Because FDA fluorescence emission can be altered by changes in cell volume (Agustí et al. 1998), the FL1 values were normalized to cell size values estimated using Eq. (1).

Statistical analysis. Assessment of significant differences among treatments $(p<0.05)$ for the growth rate, average cell density and chlorophyll content of each culture were analyzed using a 1-way ANOVA. For the variables measured by FC during the diel cycle on Day 4 , the average of each culture was analyzed using a repeated measures 1-way ANOVA. In both cases, a Student-Newman-Keuls multiple-comparisons post test was also applied to indicate where significant differences occurred.

\section{RESULTS}

Exposure to UV-A and UV-B radiation decreased the growth of Nannochloris atomus cultures, with the cultures exposed to UV-B being the most affected (Fig. 1). The growth rate showed significant differences among the 3 treatments, while the maximum cell density attained on Day 7 was only significantly different for the cultures exposed to UV-B (Table 2). The average chlorophyll content on Day 4 was slightly higher in

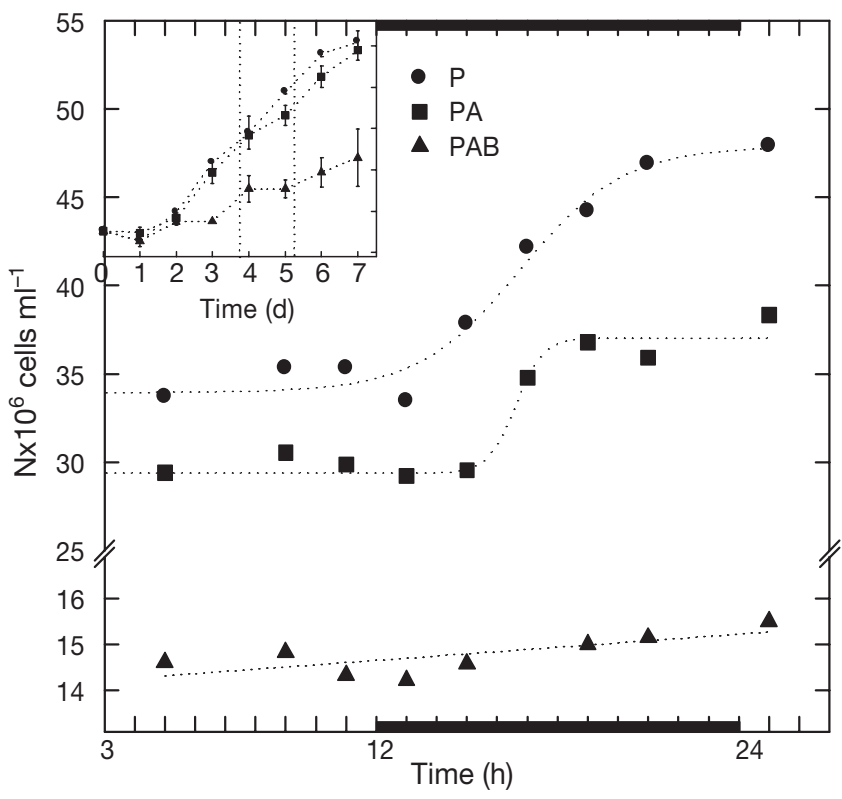

Fig. 1. Nannochloris atomus. Cellular density of cultures exposed to the spectral treatments P $(\bullet)$, PA (घ) and PAB (₫) on Day 4 of growth. Dashed lines were obtained by fitting the data to a sigmoid function. The graph in the upper corner shows the growth for $7 \mathrm{~d}$. Dark rectangles on the $x$-axis indicate the dark period. Light was on at $0 \mathrm{~h}(08: 00 \mathrm{~h})$ and it was off at $12 \mathrm{~h}(20: 00 \mathrm{~h}) . \mathrm{P}=\mathrm{PAR}, \mathrm{PA}=\mathrm{PAR}+\mathrm{UV}-\mathrm{A}$, $\mathrm{PAB}=\mathrm{PAR}+\mathrm{UVA}+\mathrm{UVB}$ 
Table 2. Growth rates $\left(\mu, \mathrm{d}^{-1}\right)$ calculated from the exponential growth phase data (see 'Material and methods') and maximal cell density attained $\left(\mathrm{N} \times 10^{6}\right.$ cells $\left.\mathrm{ml}^{-1}\right)$ on Day 7 for Nannochloris atomus cultures exposed to PAR (P), PAR+UV-A (PA) and PAR+UV-A+UV-B (PAB). The chlorophyll a content (ng chl a $\left[10^{6} \text { cells }\right]^{-1}$ ) corresponds to the average obtained on Day 4. Significant differences $(\mathrm{p}<0.05)$ with the P spectral treatment are shown as *, and significant differences between PAB and PA are shown as ${ }^{ \pm}$

\begin{tabular}{|lrcr|}
\hline & P & PA & \multicolumn{1}{c|}{ PAB } \\
\hline$\mu\left(\mathrm{d}^{-1}\right)$ & 0.46 & $0.39 *$ & $0.17^{* \mp}$ \\
$\mathrm{N} \times 10^{6}$ cells ml & & 51.91 & $14.53^{* 1}$ \\
$\mathrm{Chl}$ & 57.91 & & 16.5 \\
\hline ng chl $\left.a\left[10^{6} \text { cells }\right]^{-1}\right)$ & 25.2 & 18.2 & 16.5 \\
\hline
\end{tabular}

cultures grown under PAR than under PAR+UV-A and PAR+UV-A+UV-B, but the differences were not statistically significant (Table 2). The cultures exposed to PAR and PAR+UV-A showed tight phasing of cell division to the L:D cycle, as demonstrated by the pronounced increment in culture cell density after the beginning of darkness. In contrast, few cells divided from Day 4 to Day 5 in the cultures exposed to UV-B and no apparent increment was observed as compared with the other treatments (Fig. 1). The change in cell density over this growth period fit a sigmoidal function $\left(r^{2}=0.94,0.91\right.$ and 0.7 for P, PA and PAB, respectively), similar to those described in the literature for synchronized cells (Zachleder et al. 1997).

Chlorophyll autofluorescence (FL3), metabolic activity (FL1) and cell size (FSC, SSC) increased progressively during the light period and decreased during darkness for all the spectral treatments (Fig. 2). These variables had very clear patterns of variation, showing maxima at the end of the light phase and minima close to the end of the dark phase. Chlorophyll autofluorescence was higher in cells exposed to PAR than in cells exposed to PAR+UV-A, and much higher in cells from both treatments than in cells exposed to the treatment including UV-B (Fig. 2A).

Metabolic activity increased markedly with the beginning of the illumination. It was similar in the cultures exposed to both PAR and PAR+UV-A (Fig. 2B). On the contrary, in cultures exposed to UV-B the metabolic activity showed a smaller range of variation, with values ranging between the maximum and the minimum observed for the cultures with PAR and PAR+UVA. Because FDA fluorescence emission can be altered by changes in cell volume (Agustí et al. 1998), these values were also normalized to cell size. This correction enhanced the differences in metabolic activity between the cells exposed to UV-B and those exposed to PAR and PAR+UV-A, whose pattern of variation remained similar to the pattern before the correction
(Fig. 2C). The normalized values in the cells exposed to UV-B increased slightly during the light period and decreased during the dark period, showing values significantly smaller than those observed for the cells exposed to PAR and PAR+UV-A.

Both SSC and FSC values showed that cells exposed to UV-B were significantly larger than the cells exposed to PAR or PAR+UV-A. The latter were not significantly different (Fig. 2D,E).

\section{DISCUSSION}

Cell size, chlorophyll content and metabolic activity rose in Nannochloris atomus cells exposed to the different spectral treatments during the light period as a result of the synthesis of molecules derived from the carbon fixation process. Thus, at the end of the light period, each parental cell became big enough to produce 2 complete, but comparatively smaller, daughter cells, which was confirmed by the increases in cell density. On the contrary, the decrease in cell size, chlorophyll content and metabolic activity during darkness matched the cell division and the predominant respiratory activity until the beginning of the next light period. However, unlike the cells exposed to PAR or UV-A, the larger size of the cells exposed to UV-B was not correlated with a higher metabolic activity. The increase in cell size under UV-B exposures has already been described for DNA damaged phytoplankton (Karentz et al. 1991, Buma et al. 1996). The cell cycle is interrupted if UV-B-damaged DNA is not efficiently repaired, even though the synthesis of other cellular components not related to nuclear division goes on (Buma et al. 1996). However, cells exposed to PAR+UV-A were similarly sized to those exposed to PAR, as it is unlikely that DNA directly absorbs UV-A (Table 1). In addition, indirect DNA damage produced by oxidative stress was probably not significant on Day 4, since cells exposed to UV-A showed similar growth and metabolic activity than those exposed to PAR alone.

Chlorophyll autofluorescence, currently used as an indirect measure of the cellular chlorophyll content, was significantly affected by both UV-A and UV-B. The decrease in chlorophyll fluorescence under UVR was related to the decrease (albeit not significant) in extracted pigment content observed under both UV treatments. The autofluorescence decrease was probably also related to damage to PSII (see review by Vincent \& Neale 2000). Since the main source for the in vivo emission of chlorophyll a fluorescence is PSII, any damage to PSII will decrease the fluorescence emission detected by the cytometer (Neale et al. 1989, Sobrino et al. 2004). However, in our results, this con- 


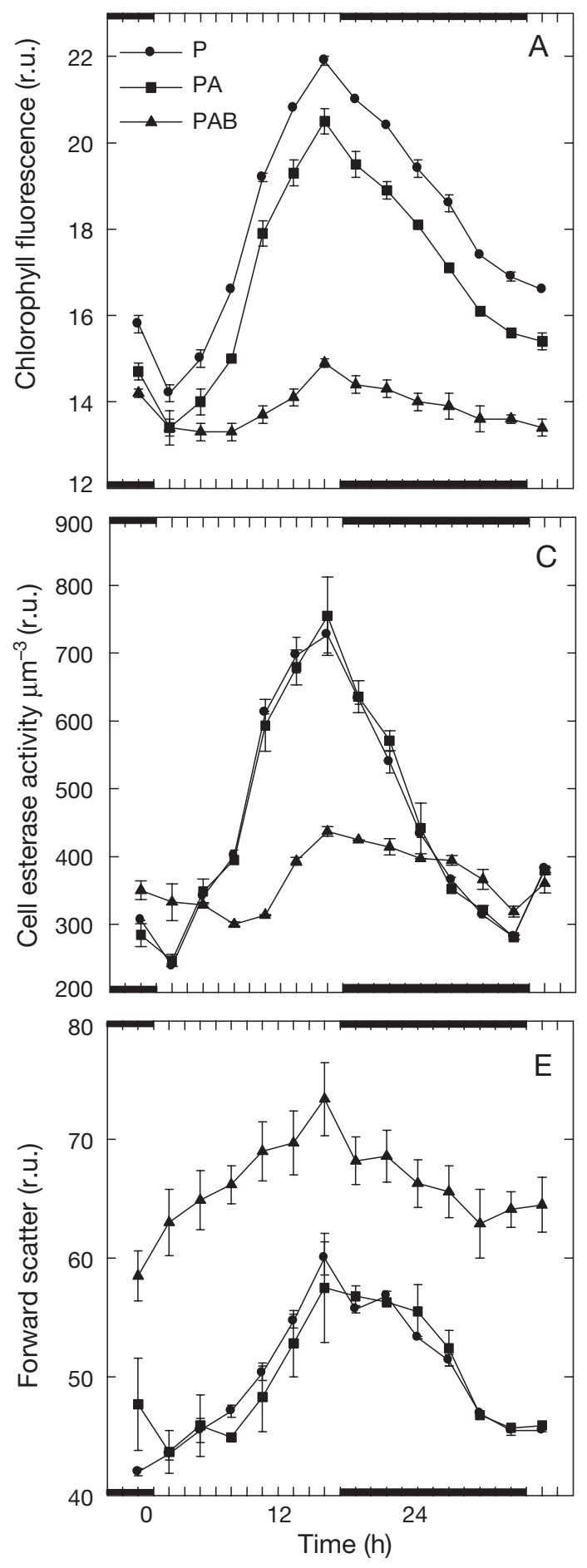

tention can be applied only to cells exposed to UV-B. Cells exposed to PAR+UV-A, although with lower initial values, showed similar rates of increase in chlorophyll fluorescence and similar metabolic activity as the cells exposed to PAR alone.

The fluorescence emission from FDA stained cells of marine microalgae has been previously correlated with the quantity of fixed carbon (Dorsey et al. 1989,

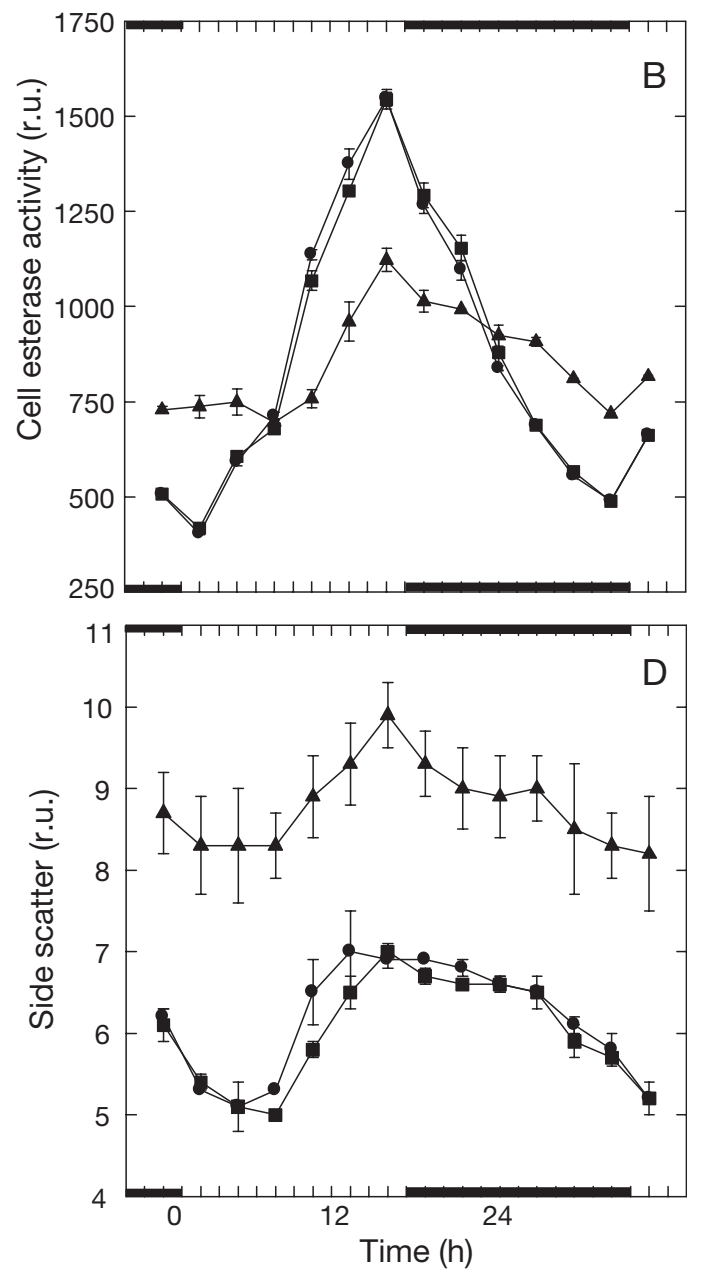

Fig. 2. Nannochloris atomus. Diel patterns of (A) chlorophyll fluorescence, (B) metabolic activity measured using a cell esterase activity assay, (C) metabolic activity normalized to cell size, and cell size measured as (D) side angle light scatter and (E) forward angle light scatter values (in relative units [r.u.]) in cultures exposed to the spectral treatments

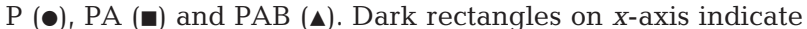
the dark period. Light was on at $0 \mathrm{~h}(08: 00 \mathrm{~h})$ and it was off at $12 \mathrm{~h}(20: 00 \mathrm{~h}) . \mathrm{P}=\mathrm{PAR}, \mathrm{PA}=\mathrm{PAR}+\mathrm{UV}-\mathrm{A}$ and $\mathrm{PAB}=$ PAR+UV-A+UV-B.

DuRand \& Olson 1998). The FDA-based method used in this study was able to detect small changes in cell esterase activity within the diel cycle as well as among the spectral treatments. Similar to the cell size but unlike the autofluorescence, the results showed that the cell esterase activity in Nannochloris atomus was highly sensitive to UV-B but not to UV-A. This can result from a different wavelength dependency of each 
target of damage. However, changes in both chlorophyll fluorescence and metabolic activity followed similar time courses under UV-B exposure. They showed a greater damaging effect during the first half of the light period and recovery during the second half, consequent with a dynamic balance between the UV damage and the cellular repair. Therefore, the accumulation of the net effect to the UV-B exposure produced maximal differences to the cultures exposed to PAR and PAR+UV-A at the end of the light period.

In Nannochloris atomus cells exposed to PAR and PAR+UV-A, the main increase in cellular density occurred during the few hours after darkness, showing that cell division was tightly synchronized (DuRand \& Olson 1998). Furthermore, in spite of the low cell density and cellular division rate observed in the UV-B-exposed cultures, the clear diel patterns found in the parameters measured by FC suggest that synchrony also occurred under UV-B exposure. Changes in cell size during the night have previously been shown to provide good estimates of the growth rate in synchronized cultures because nearly all cell division occurs during that period (Durand \& Olson 1998). For N. atomus, a good correlation $\left(\mathrm{r}^{2}=0.98\right)$ between the growth rates and the changes in cell size during the night was obtained in this study (data not shown). The existence of synchrony may imply that UV-damaged cells that did not divide during the limited time interval in the dark period, will not divide until the next dark period, and then only if they have been effectively repaired. This might disadvantage species with synchronized circadian cycles such as $N$. atomus, and affect phytoplanktonic composition. However, more studies are needed to verify this contention, since factors such as the variability in UV sensitivity between species might be enough to counteract the disadvantage created by the diel synchronicity.

This study demonstrates that Nannochloris atomus shows pronounced diel cycles of growth and metabolic activity similar to those reported for Nannochloris sp. (DuRand \& Olson 1998). In addition, FC measurements showed that the exposure to UV-A and UV-B did not alter the synchronicity in the diel cycles of cell size, chlorophyll autofluorescence and metabolic activity, but the responses were dependent on the spectral conditions. The results confirmed the relevance of UV-B damage to phytoplankton regarding growth and metabolic activity, as well as the lesser effect of the UV-A.

Acknowledgements. This work was financially supported by the Spanish Ministry of Education and Culture through AMB 97-1021-C02-02 project and fellowship to C.S. The authors thank F. L. Figueroa for providing the LI-1800 spectroradiometer and L. Franklin, P. J. Neale and J. Phillips-Kress for improving this manuscript with their suggestions.

\section{LITERATURE CITED}

Agustí S, Satta MP, Mura MP, Benavent E (1998) Dissolved esterase activity as a tracer of phytoplanktom lysis: evidence of high phytoplankton lysis rates in the NW Mediterranean. Limnol Oceanogr 43(8):1836-1849

Beardall J, Berman T, Markager S, Martinez R, Montecino V (1997) The effects of ultraviolet radiation on respiration and photosynthesis in two species of microalgae. Can J Fish Aquat Sci 54:687-696

Buma AGJ, Zemmelink HJ, Sjollema K, Gieskes WWC (1996) UVB radiation modifies protein and photosynthetic pigment content, volume and ultrastucture of marine diatoms. Mar Ecol Prog Ser 142:47-54

Buma AGJ, Boelen P, Jeffrey WA (2003) UVR-induced DNA damage in aquatic organisms. In: Helbling W, Zagarese $\mathrm{H}$ (eds) Comprehensive series in photosciences: UV effects in aquatic organisms and ecosystems. Royal Society of Chemistry, Cambridge

Cullen JJ, Lesser MP (1991) Inhibition of phytoplankton photosynthesis by ultraviolet radiation as a function of dose and dosage rate: results for a marine diatom. Mar Biol 11:83-90

Dorsey J, Yentsch CM, Mayo S, McKenna C (1989) Rapid analytical method for the assessment of cell metabolic activity in marine microalgae. Cytometry 10:622-628

DuRand MD, Olson RJ (1998) Diel patterns in optical properties of the chlorophyte Nannochloris sp.: relating individual-cell to bulk measurements. Limnol Oceanogr 43(6):1107-1118

Jacquet S, Partensky F, Marie D, Casotti R, Vaulot D (2001a) Cell cycle regulation by light in Prochlorococcus strains. Appl Environ Microbiol 67(2):782-790

Jacquet S, Partensky F, Lennon J, Vaulot D (2001b) Diel patterns of growth and division in marine picoplankton in culture. J Phycol 37:357-369

Karentz D, Cleaver JE, Mitchell DL (1991) Cell survival characteristics and molecular responses of Antarctic phytoplankton to UVB radiation. J Phycol 27:326-341

Li WKW (1994) Primary productivity of prochlorophytes, cyanobacteria and eukaryotic ultraphytoplankton: measurements from flow cytometric sorting. Limnol Oceanogr 39:169-175

Madronich S, McKenzie RL, Björn LO, Caldwell MM (1998) Changes in ultraviolet radiation reaching the Earth's surface, environmental effects of ozone depletion. J Photochem Photobiol B 46:5-19

Neale PJ, Cullen JJ, Yentsch CM (1989) Bio-optical inferences from chlorophyll a fluorescence: what kind of fluorescence is measured by flow cytometry? Limnol Oceanogr 34(8):1739-1748

Olson RJ, Chisholm SW (1986) Effects of light and nitrogen limitation on the cell cycle of the dinoflagellate Amphydinium carteri. J Plankton Res 8(4):785-793

Porra RJ, Thompson WA, Kriedemann PE (1989) Determination of accurate extinction coefficients and simultaneous equations for assaying chlorophylls $a$ and $b$ extracted with four different solvents: verification of the concentration of chlorophyll absorption spectroscopy. Biochim Biophys Acta 975:384-394

Quesada A, Mouget J, Vincent WF (1995) Growth of Antarctic cyanobacteria under ultraviolet radiation: UVA counteracts UVB inhibition. J Phycol 31:242-248

Setlow RB (1974) The wavelengths in sunlight effective in producing skin cancer: a theoretical analysis. Proc Natl Acad Sci USA 71:3363-3366

Sobrino C, Montero O, Lubian LM (2004) UV-B radiation 
increases cell permeability and damages nitrogen incorporation mechanisms in Nannochloropsis gaditana. Aquat Sci 66(4):421-429

Sobrino C, Neale PJ, Lubian LM (2005) Interaction of UVradiation and inorganic carbon supply in the inhibition of photosynthesis: spectral and temporal responses of two marine picoplankters. Photochem Photobiol 81(2): 384-393

Editorial responsibility: Otto Kinne (Editor-in-Chief), Oldendorf/Luhe, Germany
Vincent WF, Neale PJ (2000) Mechanisms of UV damage to aquatic organisms. In: de Mora SJ, Demers S, Vernet M (eds) The effects of UV radiation on marine ecosystems. Cambridge University Press, Cambridge, p 149-176

Zachleder V, Schlafli O, Boschetti A (1997) Growth-controlled oscillation in activity of histone $\mathrm{H} 1$ kinase during the cell cycle of Chlamydomonas reinhardtii (Chlorophyta). J Phycol 33:673-681

Submitted: August 16, 2004; Accepted: February 15, 2005 Proofs received from author(s): May 4, 2005 